\title{
Pengaruh Penambahan Puree Labu Kuning (Cucurbita moschata) Terhadap Karakterisitik Siomay Udang
}

\section{Effect of Addition of Pumpkin Puree (Cucurbita moschata) on the Characteristics of Shrimp Dumplings}

\author{
Ni Putu Candra Utami ${ }^{1}$, I Dewa Gde Mayun Permana ${ }^{1^{*}}$, Agus Selamet Duniaji ${ }^{1}$ \\ Program Studi Ilmu dan Teknologi Pangan, Fakultas Teknologi Pertanian, \\ Universitas Udayana, Kampus Bukit Jimbaran, Badung-Bali \\ Penulis korespondensi: ID.G.Mayun Permana, Email: mayunpermana@unud.ac.id
}

\begin{abstract}
This study aims to determine the effect of adding puree of pumpkin on the characteristics of shrimp dumplings and to determine the appropriate addition puree of pumpkin to produce shrimp dumplings with the best characteristics. The experimental design used in this study was a completely randomized design (CRD) consisting of 5 treatments, namely $0 \%, 10 \%, 20 \%, 30 \%$, and $40 \%$. All treatments were repeated 3 times in order to obtain 15 experimental units. The data obtained were analyzed by means of variance and if the treatment had a significant effect, then proceed with the Duncan Multipe Range Test (DMRT). The results showed that the addition of pumpkin pulp had a very significant effect on moisture content, crude fiber content, total $\beta$-carotene, and antioxidant activity using the $\beta$-Bleaching method. Has no significant effect on ash content, hedonic test on color, aroma, texture, taste, overall acceptance, and scoring test on color and texture. The addition of pumpkin pulp $40 \%$ had the best characteristics with water content of $61.22 \%$, ash content of $2.59 \%$, crude fiber content of $1.96 \%$, total $\beta$-carotene $0.98 \mathrm{mg} / 100 \mathrm{~g}$ and antioxidant activity of $5.31 \%$. , by the criteria of yellow color and liked, flavor liked, chewy texture and liked, taste liked and overall acceptance liked.
\end{abstract}

Keywords: shrimp dumplings, pumpkin, antioxidants.

\section{PENDAHULUAN}

Siomay dalam bahasa Mandarin disebut shaomai merupakan daging cincang yang dibungkus kulit yang tipis dari tepung terigu dan dimatangkan dengan cara dikukus. Bahan pembuatan siomay yang awalnya terbuat dari daging babi cincang, kemudian diganti dengan daging ikan segar yang gurih, seperti ikan tenggiri atau udang. Pembuatan siomay berbahan dasar udang segar dengan bahan tambahan putih telur, pati singkong, bawang merah, bawang putih, merica serta garam yang dicampur dan dibungkus dengan kulit pangsit (Muthohar, 2004). Tujuan penambahan udah pad siomay adalah untuk meningkatkan nilai gizi pada siomay karena per 100 gram udang mengandung 21 gram protein. Selain itu, penambahan udang pada pembuatan siomay juga diharapkan dapat menambah keanekaragaman produk pangan dengan olahan yang berbahan dasar udang.

Siomay selama perkembangannya sangat diminati oleh masyarakat Indonesia dan 
mudah ditemukan di tempat-tempat jajanan yang ada, bahkan banyak juga masyarakat yang kesehariannya menjadikan siomay sebagai makanan lauk-pauk alternatif. Siomay yang sering di dapat di tempat jajanan ataupun tempat lainnya belum memiliki banyak pilihan seperti variasi rasa, warna, atau keanekaragaman bahan baku yang digunakan. Salah satu penganekaragaman siomay dapat dilakukan dengan menambahkan puree labu kuning (Nessianti,2015).

Puree labu kuning yang ditambahkan pada siomay bertujuan untuk meningkatkan nilai gizi pada siomay diantaranya adalah kandungan antioksidan, beta karoten, serat, dan memberikan variasi rasa, warna, atau keanekaragaman bahan baku pada produk siomay. Penggunaan udang pada pembuatan siomay juga dapat menambah nilai gizi serta cita rasa pada siomay,

Keberadaan labu kuning di Indonesia sangat melimpah, tetapi pemanfaatan labu kuning di kalangan masyarakat masih sangat sedikit. Hal ini juga yang menjadi pertimbangan di dalam pemilihan labu kuning sebagai bahan baku dalam pembuatan siomay agar nilai ekonomis labu kuning meningkat. Kandungan gizi labu kuning per 100 gram diantaranya karbohidrat sebesar $69 \mathrm{~g}$, protein sebesar 1,1 g, lemak sebesar 0,3 g, beta karoten sebesar 17,25 mg/100g, vitamin B sebesar $0,08 \mathrm{mg}$, vitamin $\mathrm{C}$ sebesar $52 \mathrm{mg}$, serat kasar sebesar $0,87 \mathrm{~g}$, fosfor sebesar 64 mg, kalsium sebesar $45 \mathrm{mg}$, air 91,2 ml, dan kalori sebesar 29 kkal (Anon., 2005). Serat yang tinggi dalam labu juga memiliki manfaat untuk pencernaan, demam, diare dan mengatasi peradangan (Gardjito, 2013). Beta karoten merupakan salah satu jenis karotenoid yang mempunyai aktivitas biologis sebagai provitamin-A, dan dapat berperan sebagai antioksidan yang efektif pada konsentrasi oksigen rendah (Sinaga, 2011). Labu kuning saat ini lebih banyak diolah menjadi tepung, sehingga diperlukan cara pengolahan yang berbeda untuk menghasilkan produk pangan dengan nilai gizi yang cukup tinggi. Salah satu cara yang dapat dilakukan dengan mengolah labu kuning menjadi puree dan ditambahkan pada produk pangan yang sudah umum berada di pasaran khususnya siomay. Keunggulan puree labu kuning dibandingkan tepung labu kuning adalah proses pengolahannya yang lebih cepat dan kandungan gizinya tidak banyak yang hilang saat proses pengolahan.

Labu kuning memiliki tekstur yang lembut dan memiliki rasa sedikit manis sehingga mempengaruhi karakteristik siomay udang yang dihasilkan. jika terlalu banyak puree labu kuning yang ditambahkan akan membuat tekstur siomay menjadi lembek dan rasa dari siomay yang dihasilkan akan manis, sedangkan jika penambahan puree yang terlalu sedikit akan membuat rasa dan warna labu kuning pada siomay udang tidak muncul. Untuk itu perlu dilakukan penelitian untuk 
mengetahui berapa penambahan puree labu kuning yang tepat sehingga diperoleh karakteristik siomay udang terbaik.

\section{METODE PENELITIAN}

\section{Tempat dan Waktu}

Penelitian ini dilaksanakan di Laboratorium Pengolahan Pangan, Laboratorium Analisis Pangan, Laboratorium Rekayasa Proses dan Pengendalian Mutu Fakultas Teknologi Pertanian Universitas Udayana. Waktu penelitian ini berlangsung dari Januari - Maret 2020.

\section{Bahan dan Alat}

Bahan-bahan yang digunakan dalam melaksanakan penelitian ini terdiri dari: bahan baku, bahan tambahan, dan bahan kimia. Bahan baku terdiri dari udang segar jenis vannamei yang diperoeh di Pasar Ikan Kedonganan, dan labu kuning jenis bokor yang sudah matang dengan ciri-ciri kulit buah agak sedikit kecoklatan dan keras serta bahan tambahan seperti tapioka, telur ayam, bawang merah, bawang putih, garam dan merica bubuk diperoleh di Pasar Badung, Denpasar. Bahan kimia yang digunakan dalam melakukan analisis yakni: methanol (Merck), aquades, K2SO4 (Sigma), $\mathrm{NaOH}$ (Merck), NaSO4 (Merck), petroleum benzene (Merck), kloroform (Emsure), etanol (Sigma), asam linoleate (Sigma), beta karoten (Sigma), aseton (Sigma), alkohol (Sigma).
Alat-alat yang digunakan dalam penelitian ini adalah: timbangan analitik (Shimadzu), timbangan, baskom, serbet makan, pisau, sendok, blender (Phillips), panci pengukus, mangkuk, erlenmeyer (Pyrex), vortex, spektrofotometer (Genesys $10 S U V$ - U15), eksikator, lumpang, oven, gelas ukur (Pyrex), pipet tetes, corong, kertas whatman No.1, kompor (Rinnai), waterbath, tabung reaksi (Pyrex), dan labu ukur (Pyrex).

\section{Rancangan Percobaan}

Rancangan percobaan yang digunakan dalam penelitian ini menggunakan Rancangan Acak Lengkap (RAL) dengan perlakuan penambahan puree labu kuning terdiri dari 5 perlakuan, yaitu :

P0 = puree labu kuning 0\%, P1 = puree labu kuning 10\%, P2 = puree labu kuning 20\%, P3 $=$ puree labu kuning 30\%, P4 = puree labu kuning $40 \%$.

Masing-masing perlakuan diulang sebanyak 3 kali sehingga diperoleh 15 unit percobaan. . Data yang diperoleh kemudian dianalisis dengan sidik ragam, apabila perlakuan berpengaruh terhadap variabel yang diamati maka dilanjutkan dengan Duncan multiple range test (DMRT) (Gomez dan Gomez, 1995).

\section{Variabel yang Diamati}

Variabel yang diamati dalam penelitian ini adalah kadar air dengan metode pengeringan, kadar abu dengan metode pengabuan (Sudarmadji dkk., 1997), total $\beta$ - 
Karoten (Nielsen, 1995), aktivitas antioksidan dengan metode $\beta$-karoten bleaching (Aznam dan Amanah, 2016), penentuan kadar serat kasar dengan metode hidrolisis asam basa (Sudarmadji dkk., 1997) dan sifat sensoris diuji dengan uji hedonik terhadap warna, rasa, tekstur, aroma, dan penerimaaan keseluruhan dan uji skoring terhadap warna dan tekstur (Soekarto, 1985).

\section{Pelaksanaan Penelitian} Pembuatan Puree Labu Kuning

Labu kuning dikupas dan dihilangkan bijinya, kemudian dipotong menjadi kecil dan dicuci, kemudian dikukus selama 10 menit dengan suhu $70^{\circ} \mathrm{C}$. Setelah proses pengukusan selesai, labu kuning dihancurkan dengan blender dengan waktu 5 menit. Setelah semua proses selesai, maka jadilah puree labu kuning.

\section{Pembuatan Siomay Udang}

Udang jenis vannamei dicuci dan dikupas guna memisahkan kepala, kulit, dan kaki udang. Udang yang sudah dikupas diblender dengan waktu 5 menit. Semua bahan yakni: puree labu kuning, tapioka, putih telur, garam, bawang putih, bawang merah, dan merica bubuk sesuai formula (Tabel 2) bahanbahan tersebut kemudian diaduk hingga tercampur rata. Setelah tercampur rata, dibentuk dan dibungkus mengggunakan kulit pangsit. Setelah siomay selesai dibentuk dan dibungkus, lalu siomay dikukus dengan waktu 20 menit dengan suhu $70^{\circ} \mathrm{C}$.

Tabel 1. Formulasi siomay udang puree labu kuning

\begin{tabular}{llrrrrr}
\hline \multirow{2}{*}{ No. } & \multicolumn{1}{c}{ Komposisi } & \multicolumn{5}{c}{ Perlakuan } \\
\cline { 3 - 7 } & & P0 & P1 & P2 & P3 & P4 \\
\hline 1 & Udang Segar (\%) & 100 & 100 & 100 & 100 & 100 \\
2 & Puree Labu Kuning (\%) & 0 & 10 & 20 & 30 & 40 \\
3 & Tapioka (\%) & 30 & 30 & 30 & 30 & 30 \\
4 & Putih Telur (\%) & 15 & 15 & 15 & 15 & 15 \\
5 & Garam (\%) & 5 & 5 & 5 & 5 & 5 \\
6 & Bawang Putih (\%) & 5 & 5 & 5 & 5 & 5 \\
7 & Bawang Merah (\%) & 5 & 5 & 5 & 5 & 5 \\
8 & Merica Bubuk (\%) & 5 & 5 & 5 & 5 & 5 \\
\hline
\end{tabular}

Keterangan: seluruh \% di atas berdasarkan 100 gram berat udang. Sumber: (Nessianti 2015) yang telah dimodifikasi. 


\section{HASIL DAN PEMBAHASAN}

\section{Kadar Air}

Hasil sidik ragam menunjukkan bahwa penambahan puree labu kuning berpengaruh sangat nyata $(\mathrm{P}<0,01)$ terhadap kadar air pada siomay udang. Kadar air pada perlakuan berkisar antara 48,37\% sampai dengan $61,22 \%$ pada Tabel 2. Kadar air tertinggi terdapat pada perlakuan penambahan puree labu kuning 40\% dimana angka tersebut melewati batas maksimum standarisasi nasional siomay ikan yang terdapat pada Tabel 2. Hal ini disebabkan kadar air yang terdapat pada labu kuning cukup tinggi sehingga penambahan puree labu kuning pada setiap perlakuan mengalami peningkatan kadar air (Rivo dkk., 2015). Tingginya kandungan air yang terdapat pada suatu bahan makanan akan mempercepat proses kerusakan baik secara mikrobiologis, kimiawi maupun enzimatik (Sudarmadji dkk., 1989). Puree labu kuning memiliki kadar air yakni 90,78\% (Santoso dkk., 2013) sehingga dengan penambahan puree labu kuning yang semakin besar akan membuat kandungan kadar air pada siomay udang semakin tinggi.

Kadar air merupakan karakteristik kimia yang sangat penting dalam bahan pangan karena dapat mempengaruhi tekstur, kenampakan dan citarasa makanan (Winarno,1997). Menurut Rakhmah (2012) bebera hal dapat mempengaruhi kadar air dalam suatu produk pangan, diantaranya adalah jenis bahan dan komponen.

\section{Kadar Abu}

Hasil sidik ragam menunjukkan bahwa penambahan puree labu kuning berpengaruh tidak nyata $(\mathrm{P}>0,05)$ terhadap kadar abu pada siomay udang. Total kadar abu dari semua perlakuan tergolong cukup tinggi yakni $2,59 \%$, dimana angka tersebut melewati batas maksimum standarisasi nasional yang tertera pada Tabel 2. Jumlah penambahan puree tersebut tergolong besar, tetapi kandungan mineral pada siomay cukup rendah sehingga hasilnya menunjukkan berpengaruh tidak nyata terhadap kadar abu.

Kadar abu merupakan campuran dari komponen anorganik atau mineral yang terdapat pada suatu bahan pangan. Bahan pangan terdiri dari bahan organik dan air, sedangkan sisanya merupakan unsur-unsur mineral. Kadar abu tersebut dapat menunjukkan total mineral dalam suatu bahan pangan. Bahan-bahan organik dalam proses pembakaran akan terbakar tetapi komponen anorganiknya tidak, karena itulah disebut sebagai kadar abu.

\section{Kadar Serat Kasar}

Hasil sidik ragam menunjukkan bahwa penambahan puree labu kuning berpengaruh sangat nyata $(P<0,01)$ terhadap kadar serat kasar pada siomay udang. Kadar 
serat kasar pada perlakuan berkisar antara $0,82 \%$ sampai dengan $1,96 \%$ yang dapat dilihat pada Tabel 6. Kadar serat kasar tertinggi terdapat pada perlakuan P4 (penambahan puree labu kuning 40\%) dan terendah pada perlakuan P0 (penambahan puree labu kuning 0\%). Menurut Hendrasty (2003) labu kuning memiliki kadar serat sebesar 2,90\%. Sehingga semakin banyak penambahan puree labu kuning, kadar serat pada siomay akan semakin tinggi.
Serat hanya terdapat dalam bahan pangan nabati, dan kadarnya bervariasi menurut jenis bahan. Menurut Winarno (2002) selulosa dan hemiselulosa lebih sukar untuk diuraikan dan mempunyai sifat-sifat sebagai berikut, yaitu memberi bentuk atau struktur pada tanaman, tidak larut dalam air dingin maupun air panas, tidak dapat dicerna oleh cairan pencernaan manusia sehingga tidak dapat menghasilkan energi serta dapat membantu melancarkan pencernaan.

Tabel 2. Nilai rata-rata kadar air, kadar abu, kadar serat kasar

\begin{tabular}{cccc}
\hline $\begin{array}{c}\text { Penambahan Puree Labu } \\
\text { Kuning }\end{array}$ & $\begin{array}{c}\text { Kadar Air } \\
(\%)\end{array}$ & $\begin{array}{c}\text { Kadar Abu } \\
(\%)\end{array}$ & $\begin{array}{c}\text { Serat Kasar } \\
(\%)\end{array}$ \\
\hline P0 $(0 \%)$ & $48,37 \pm 2,06 \mathrm{~d}$ & $2,59 \pm 0,11 \mathrm{a}$ & $0,82 \pm 0,15 \mathrm{~d}$ \\
P1 (10\%) & $53,41 \pm 1,27 \mathrm{c}$ & $2,59 \pm 0,81 \mathrm{a}$ & $1,09 \pm 0,05 \mathrm{c}$ \\
P2 (20\%) & $56,39 \pm 2,16 \mathrm{~b}$ & $2,59 \pm 0,17 \mathrm{a}$ & $1,59 \pm 0,02 \mathrm{~b}$ \\
P3 (30\%) & $59,09 \pm 0,86 \mathrm{ab}$ & $2,59 \pm 1,00 \mathrm{a}$ & $1,88 \pm 0,15 \mathrm{a}$ \\
P4 (40\%) & $61,22 \pm 1,34 \mathrm{a}$ & $2,59 \pm 0,28 \mathrm{a}$ & $1,96 \pm 0,03 \mathrm{a}$ \\
\hline
\end{tabular}

Keterangan : Nilai rata-rata yang diikuti oleh huruf yang berbeda pada kolom yang sama menunjukan perlakuan berbeda nyata $(\mathrm{P}<0,05)$.

\section{Total $\beta$-Karoten}

Hasil sidik ragam menunjukkan bahwa penambahan puree labu kuning berpengaruh sangat nyata $(\mathrm{P}<0,01)$ terhadap kandungan beta karoten pada siomay udang. Kandungan beta karoten pada perlakuan berkisar antara $0,65 \mathrm{mg} / 100 \mathrm{~g}$ sampai dengan 0,98 mg/100g yang dapat dilihat pada Tabel 3 . Kandungan beta karoten tertinggi terdapat pada perlakuan P4 (penambahan puree labu kuning 40\%) dan terendah pada perlakuan P0 (penambahan puree labu kuning 0\%). Hal tersebut menunjukkan bahwa semakin tinggi penambahan puree labu kuning maka semakin tinggi juga kandungan beta karoten yang terdapat pada siomay udang. Menurut Anam dan Handajani (2010) labu kuning memiliki kandungan beta karoten yang tinggi pada daging buahnya, sehingga semakin banyak penambahan puree labu kuning yang maka kandungan beta karoten siomay udang semakin meningkat. Labu kuning dikenal kaya akan karotenoid yaitu beta karoten yang merupakan sumber antioksidan di dalam labu 
kuning. Hasil penelitian Norshazila (2012) menunjukkan bahwa labu kuning mengandung beta karoten $92,21 \%$ dari total karotenoid.

\section{Aktivitas Antioksidan}

Hasil sidik ragam menunjukkan bahwa penambahan puree labu kuning berpengaruh sangat nyata $(\mathrm{P}<0,01)$ terhadap aktivitas antioksidan pada siomay udang. Aktivitas antioksidan pada perlakuan berkisar antara $12,27 \%$ sampai dengan 5,31\% yang dapat dilihat pada Tabel 3. Tingkat oksidasi tertinggi terdapat pada perlakuan P0 (penambahan puree labu kuning 0\%) dan terendah pada perlakuan P4 (penambahan puree labu kuning 40\%). Hal ini menunjukkan bahwa semakin tinggi penambahan puree labu kuning maka tingkat oksidasi akan semakin rendah. Metode $\beta$-karoten bleaching merupakan suatu metode untuk mengukur aktivitas antioksidan dalam menghambat peroksidasi lipid. Metode ini didasarkan pada kemampuan antioksidan untuk mencegah atau menghambat pemudaran warna jingga karoten akibat oksidasi dari radikal peroksida yang terbentuk pada reaksi oksidasi asam linoleat (Tahir dkk., 2017). Tingkat oksidasi berbanding terbalik dengan kemampuan senyawa mencegah reaksi oksidasi, sehingga semakin rendah tingkat oksidasinya maka kemampuan untuk mencegah reaksi oksidasi menjadi lebih baik begitu pula sebaliknya. Hal ini disebabkan karena radikal bebas yang berasal dari oksidasi asam linoleat akan menyerang ikatan rangkap terkonjugasi dari beta karoten (Hadiwibowo, 2010), sehingga diperlukan penambahan sampel yang mengandung $\beta$-karoten untuk menghambat terjadinya proses oksidasi. Semakin tinggi kandungan $\beta$-karoten sampel maka penetralan radikal bebas asam linoleat akan semakin cepat.

\section{Tabel 3. Nilai rata-rata total beta karoten dan aktivitas antioksidan}

\begin{tabular}{ccc}
\hline $\begin{array}{c}\text { Penambahan puree labu } \\
\text { kuning }\end{array}$ & $\begin{array}{c}\text { Beta karoten } \\
(\mathrm{mg} / 100 \mathrm{~g})\end{array}$ & $\begin{array}{c}\text { Aktivitas Antioksidan } \\
(\%)\end{array}$ \\
\hline P0 $(0 \%)$ & $0,65 \pm 0,01 \mathrm{e}$ & $12,37 \pm 0,19 \mathrm{e}$ \\
P1 $(10 \%)$ & $0,78 \pm 0,01 \mathrm{~d}$ & $11,60 \pm 0,44 \mathrm{~d}$ \\
P2 $(20 \%)$ & $0,85 \pm 0,02 \mathrm{c}$ & $8,68 \pm 0,34 \mathrm{c}$ \\
P3 (30\%) & $0,92 \pm 0,01 \mathrm{~b}$ & $7,21 \pm 0,27 \mathrm{~b}$ \\
P4 (40\%) & $0,98 \pm 0,01 \mathrm{a}$ & $5,31 \pm 0,15 \mathrm{a}$ \\
\hline
\end{tabular}

Keterangan: Nilai rata-rata yang diikuti oleh huruf yang berbeda pada kolom yang sama menunjukan perlakuan berbeda nyata $(\mathrm{P}<0,05)$. 


\section{Sifat Sensori}

Pada penelitian ini evaluasi sensoris dilakukan dengan uji hedonik dan uji skoring. Uji hedonik dilakukan terhadap warna, aroma, tekstur, rasa dan penerimaan keseluruhan, sedangkan uji skoring dilakukan terhadap tekstur dan warna. Nilai rata-rata uji hedonik terhadap warna, aroma, tekstur, rasa, penerimaan keseluruhan dan uji skoring terhadap tekstur dan warna dapat dilihat pada Tabel 4

\section{Warna}

Hasil sidik ragam menunjukan bahwa perlakuan penambahan puree labu kuning berpengaruh tidak nyata $(\mathrm{P}>0,05)$ terhadap warna (uji hedonik) siomay udang. Kriteria yang dimiliki yakni suka. Hasil sidik ragam menunjukan bahwa perlakuan penambahan puree labu kuning berpengaruh tidak nyata $(\mathrm{P}>0,05)$ terhadap warna (uji skoring) siomay udang. Kriteria warna yang dimiliki yakni kuning. Menurut Winarno (1997) bahwa warna merupakan faktor penting dalam menentukan penerimaan suatu produk oleh konsumen karena tampilan visual yang pertama kali dilihat.

\section{Aroma}

Hasil sidik ragam menunjukan bahwa perlakuan penambahan puree labu kuning berpengaruh tidak nyata $(\mathrm{P}>0,05)$ terhadap aroma (uji hedonik) pada siomay udang. Kriteria yang dimiliki yakni suka. Hal ini menunjukkan bahwa panelis dapat menerima aroma siomay udang dengan baik.

Tabel 4. Nilai rata-rata uji hedonik warna, aroma, rasa, penerimaan keseluruhan dan uji skoring tekstur dan warna siomay udang

\begin{tabular}{cccccccc}
\hline & \multicolumn{3}{c}{ Uji hedonik } & & \multicolumn{2}{c}{ Uji skoring } \\
\hline $\begin{array}{c}\text { Penambahan } \\
\text { puree labu } \\
\text { kuning }\end{array}$ & Warna & Aroma & Tekstur & Rasa & $\begin{array}{c}\text { Penerimaan } \\
\text { keseluruhan }\end{array}$ & Tekstur & Warna \\
\hline P0 $(0 \%)$ & $3,36 \mathrm{a}$ & $3,64 \mathrm{a}$ & $3,08 \mathrm{a}$ & $3,72 \mathrm{a}$ & $4,16 \mathrm{a}$ & $3,32 \mathrm{a}$ & $1,68 \mathrm{a}$ \\
P1 $(10 \%)$ & $3,48 \mathrm{a}$ & $3,68 \mathrm{a}$ & $3,08 \mathrm{a}$ & $3,72 \mathrm{a}$ & $4,16 \mathrm{a}$ & $3,4 \mathrm{a}$ & $2,12 \mathrm{a}$ \\
P2 (20\%) & $3,64 \mathrm{a}$ & $3,68 \mathrm{a}$ & $3,88 \mathrm{a}$ & $3,76 \mathrm{a}$ & $4,16 \mathrm{a}$ & $3,6 \mathrm{a}$ & $2,88 \mathrm{a}$ \\
P3 $(30 \%)$ & $3,68 \mathrm{a}$ & $3,68 \mathrm{a}$ & $3,84 \mathrm{a}$ & $3,8 \mathrm{a}$ & $4,2 \mathrm{a}$ & $3,68 \mathrm{a}$ & $3,04 \mathrm{a}$ \\
P4 (40\%) & $3.76 \mathrm{a}$ & $3,08 \mathrm{a}$ & $3,95 \mathrm{a}$ & $3,48 \mathrm{a}$ & $4,28 \mathrm{a}$ & $3,72 \mathrm{a}$ & $3,44 \mathrm{a}$ \\
\hline
\end{tabular}

Keterangan : Nilai rata-rata yang diikuti oleh huruf yang sama pada kolom yang sama menunjukkan perlakuan yang berbeda nyata $(\mathrm{P}<0,01)$.

\section{Tekstur}

Hasil sidik ragam menunjukan bahwa perlakuan penambahan puree labu kuning berpengaruh tidak nyata $(\mathrm{P}>0,05)$ terhadap tekstur (uji hedonik) pada siomay udang. Kriteria yang dimiliki yakni suka. Hasil sidik 
ragam menunjukan bahwa perlakuan penambahan puree labu kuning berpengaruh tidak nyata $(\mathrm{P}>0,05)$ terhadap tekstur (uji skoring) siomay udang. Kriteria yang dimiliki yakni kenyal.

\section{Rasa}

Hasil sidik ragam menunjukan bahwa perlakuan penambahan puree labu kuning berpengaruh tidak nyata $(\mathrm{P}>0,05)$ terhadap rasa (uji hedonik) pada siomay udang. Kriteria yang dimiliki yakni suka. Rasa merupakan salah satu faktor terpenting dalam penilaian suatu produk. Menurut Meilgaard, dkk (2000) bahwa penilaian rasa dilakukan oleh indera pengecap rasa manusia ketika mengkonsumsi makanan atau minuman.

\section{Penerimaan Keseluruhan}

Hasil sidik ragam menunjukan bahwa perlakuan penambahan puree labu kuning berpengaruh tidak nyata $(\mathrm{P}>0,05)$ terhadap penerimaan keseluruhan (uji hedonik) siomay udang. Nilai rata-rata uji hedonik terhadap penerimaan keseluruhan siomay udang yakni dengan kriteria suka. Hal ini menunjukan bahwa panelis dapat menerima siomay udang dari segi warna, aroma, tekstur dan rasa.

\section{KESIMPULAN DAN SARAN}

\section{Kesimpulan}

Penambahan puree labu kuning berpengaruh sangat nyata terhadap kadar air, serat kasar, $\beta$ - karoten, aktivitas antioksidan, tetapi berpengaruh tidak nyata terhadap kadar abu, uji hedonik terhadap aroma, rasa, tekstur, warna, skoring tekstur, warna serta penerimaan keseluruhan.

Perlakuan terbaik pada penelitian ini yaitu pada penambahan puree labu kuning 40\% (P4) menghasilkan karakteristik siomay udang terbaik dengan: kadar air $61,22 \%$, kadar abu 2,29\%, kadar serat kasar 1,96\%, $\beta$-karoten $0,98 \mathrm{mg} / 100 \mathrm{~g}$ dan aktivitas antioksidan 5,31 $\%$, penerimaan keseluruhan sangat suka, memiliki warna orange kekuningan, aroma disukai panelis, dan teksturnya sangat kenyal.

\section{Saran}

1. Pengolahan siomay udang labu kuning dapat dilakukan dengan penambahan puree labu kuning 40\%.

2. Perlu dilakukan penelitian lebih lanjut terkait umur simpan serta kualitas mikrobiologi siomay udang puree labu kuning.

\section{DAFTAR PUSTAKA}

Anam, C dan S. Handajani. 2010. Mi Kering Waluh (Cucurbita moschata) dengan Antioksidan Dan Pewarna Alami. Caraka Tani XXV No.1.

Anonimus. 2005. Daftar Komposisi Bahan Makanan. Depkes RI : Jakarta.

Aznam, N. dan I. Amanah. 2016. Penentuan kadar total fenol dan uji aktivitas antioksidan kombinasi ekstrak sarang semut (Myrmecodia pendens Merr. \& L.M. Perry) dan ekstrak kencur 
(Kaempferia galanga Linn.) dengan metode $\beta$-carotene bleaching. Jurnal Kimia Dasar. 21 (3) : 1-9

Gardjito, Murdijati, dkk. 2013. Pangan Nusantara Karakteristik dan Prospek untuk Percepatan Diversifikasi Pangan. Jakarta: Kencana Prenada Media Group.

Gomez, K. A. dan A. A. Gomez. 1995. Prosedur Statistik Untuk Penelitian Pertanian.

UI Press. Jakarta.

Hadiwibowo, T. 2010. Penentuan aktivitas antioksidan ekstrak etanol daun bandotan (Ageratum conyziodes L.) melalui ekstraksi gelombang mikro. Skripsi. Fakultas Teknik. Universitas Indonesia. Depok.

Meilgaard, dkk, 2000. Sensory evaluation techniques. Boston: CRC

Muthohar, Setyanova. 2004. Pemanfaatan Ikan Menjadi Makanan Olahan Akan Meningkatkan Daya Jual Hasil Perikanan Secara Langsung. Jakarta: Penebar Swadaya.

Nessianti. A, dan R. Dewi. 2015. Pengaruh penambahan puree labu siam (Sechium Edule) terhadap sifat organoleptik siomay ikan tenggiri (Scomberomorus Commersoni). Jurnal e-boga 4(3): 79-84.

Nielsen, S. S. 2003. Introduction to Food Analysis. Di dalam Nielsen, S. S. (ed.). Food Analysis 3rd ed. Kluwer Academic/Plenum Publishers. New York.

Norshazila, S., *Irwandi, J., Othman, R. and Yumi Zuhanis, H. H. (2012). Scheme of Obtaining $\beta$-carotene Standard from Pumpkin (Cucurbita moschata) Flesh. Malaysia: International Food Research Journal, 19(2): 531- 535

Rakhmah, Y. 2012. Studi Pembuatan Bolu dari Tepung Ubi Jalar (Ipomoea batatas L.). Skripsi. Fakultas Teknologi Pertanian, Institut Pertanian Bogor. Bogor.

Respati, A. N. 2010. Pengaruh penggunaan pasta labu kuning (Cucurbita moschata) untuk substitusi tepung terigu dengan penambahan tepung angkak dalam pembuatan mie kering. Skripsi. Fakultas Pertanian. Universitas Sebelas Maret. Surakarta

Rivo H., Lucia M., dan L Lalujan. 2015. Pengaruh Penambahan Labu Kuning (cucurbita mochtata) Terhadap Kualitas Fisikokimia Dodol. Jurnal Ilmu dan Teknologi Pangan Fakultas Pertanian.

Santoso, dkk. 2013. Materi dan Pembelajaran Bahasa Indonesia, (Banten : Universitas Terbuka)

Sinaga, S. 2011. Pengaruh Substitusi Tepung Terigu Dan Jenis Penstabil Dalam Pembuatan Cookies Labu Kuning. Skripsi. Tidak Dipublikasikan. USU, Medan.

Soekarto, S.T. 1985. Penilaian Organoleptik Untuk Industri Pangan dan Pertanian.

Bharata Karya Aksara. Jakarta.

Sudarmadji, S. B. Haryono dan Suhardi. 1997. Prosedur Analisa Untuk Bahan Makanan dan Pertanian. Liberty. Yogyakarta.

Tahir, M., Z. Abidin, and N. Sukmawati. 2017. Antioxidant activityof hydrolyzed black soybean (Glycine Soja Linn. Sieb.) by $\beta$ carotene bleacing. Journal of Pharmaceutical and Medicinal Sciences 2(1): 1-4.

Winarno, F. G. 1997. Kimia Pangan dan Gizi. Gramedia Pustaka Utama. Jakarta. 